\title{
To study and compare the effect of vaginal sildenafil and estradiol valerate on endometrial thickness, blood flow and pregnancy rates in infertile women undergoing intrauterine insemination
}

\author{
Suchika Mangal $^{1,2} *$, Shuchita Mehirishi ${ }^{1}$
}

\author{
${ }^{1}$ Department of Obstetrics and Gynaecology, IMSRC, JNU Hospital, Jaipur, Rajasthan, India \\ ${ }^{2}$ Department of Obstetrics and Gynaecology, SMS Medical College and attached Hospitals, Jaipur, Rajasthan, India
}

Received: 08 May 2016

Accepted: 02 June 2016

*Correspondence:

Dr. Suchika Mangal,

E-mail: suchika14@yahoo.in

Copyright: () the author(s), publisher and licensee Medip Academy. This is an open-access article distributed under the terms of the Creative Commons Attribution Non-Commercial License, which permits unrestricted non-commercial use, distribution, and reproduction in any medium, provided the original work is properly cited.

\section{ABSTRACT}

Background: The objective of this study was to study and compare the effect of vaginal sildenafil citrate and estradiol valerate on endometrial thickness, blood flow and pregnancy rates in infertile women undergoing intrauterine insemination (IUI).

Methods: It is a comparative prospective study including 100 women with primary or secondary infertility with stimulated cycles undergoing IUI. Patients with thin endometrium were randomly distributed in two groups. In group A, 50 patients were included and given sildenafil citrate $25 \mathrm{mg}$ vaginally every 6 hours from day $8^{\text {th }}$ of the cycle. In group B, 50 patients were given tablet estradiol valerate $2 \mathrm{mg} \mathrm{6-8}$ hourly. Patients were evaluated by trans-vaginal sonography (TVS) on day $13^{\text {th }}$ of cycle for endometrial thickness and pattern with number and size of Graffian follicle.

Results: Mean endometrial thickness at the time of hCG trigger was $9.42 \mathrm{~mm}$ in sildenafil group and $9.94 \mathrm{~mm}$ in estradiol group (p value 0.14). 64\% patients given sildenafil vaginally had vascularity up to zone 3 whereas $48 \%$ patients given estradiol valerate orally had zone 3 endometrial vascularity ( $\mathrm{p}$ value $=0.038$ ). The clinical pregnancy rates were $10(20 \%)$ in group 1 and 7 (14\%) in group 2 after 3 cycles of IUI. (p value $=0.042$ ).

Conclusions: Both estradiol valerate and Sildenafil citrate can be used for improving the endometrium. Sildenafil when compared to estradiol valerate has better results as far as endometrial vascularity is concerned and marginally increased pregnancy outcome in patients undergoing IUI.

Keywords: Infertility, Sildenafil, Estradiol valerate, Endometrial thickness

\section{INTRODUCTION}

Infertility is defined as the inability to conceive after one year of unprotected intercourse. Although endometrial factor and implantation failure are known causes of female infertility, the impact of interventions improving it has not been widely studied in an unexplained infertile population of patients undergoing IUI. New clinical treatments, such as therapeutic endometrial biopsy/injury, have gained recent attention to correct the so-called endometrial factor infertility., ${ }^{1,2}$ However, endometrial development during IUI cycles has been less studied.

One of the strongest predictors of implantation is endometrial thickness. A number of reports have shown that embryo implantation and clinical pregnancy rates (PRs) are significantly higher in patients with an endometrial thickness $>9 \mathrm{~mm}^{3,4}$ Thin endometrium, generally measuring $<7 \mathrm{~mm}$, are thought to be less able to support implantation and pregnancy. ${ }^{5}$ 
The thickness of the endometrium is dependent on several influences including reproductive age, phase of menstrual cycle, ovarian hormone (estrogen and progesterone) concentration, and endometrial hormone receptor density. ${ }^{6,7}$ Available treatments for thin, unresponsive endometrium are limited and largely empiric or experimental including high doses of estrogens, HCG, piroxicam and granulocyte colony stimulating factor. ${ }^{8}$ Treatments, such as acetylsalicylic acid, have also been proposed. The results of this intervention are mixed. ${ }^{9,10}$ Most of these methods are proposed to function in a similar manner, by increasing blood flow to the endometrium and allowing for its thickening and development. Vaginal sildenafil citrate is another treatment that has been suggested for its ability to relax vascular smooth muscle through a cyclic guanosine monophosphate-mediated pathway, and improve uterine artery blood flow. Changes in the endometrial vascularity appear on color Doppler examination, which may reflect the histologic changes described by the pathologists.

The endometrial and periendometrial areas can be divided into the following four zones ${ }^{11}$

Zone 1: A $2 \mathrm{~mm}$ thick area surrounding the hyperechoic outer layer of endometrium.

Zone 2: The hyperechoic outer layer of endometrium.

Zone 3: The hypoechoic inner layer of endometrium.

Zone 4: The endometrial cavity.

\section{METHODS}

It was a hospital based comparative prospective study done in IVF centre, SMS Medical College, Jaipur, India over a period of ten months (July 14-April 15) including 100 women with primary or secondary infertility. Women $<40$ years of age requiring IUI with either husband or donor semen were included. Exclusion criteria were bilateral tubal factor, women age $>40$, husband total sperm count $<15$ million to limit confounding. Patients were either stimulated with clomiphene citrate or gonadotropin's depending on the age, hormonal status and previous cycle response. Patients with thin endometrium (Day 8 ET $<7 \mathrm{~mm}$ ) were randomly distributed in two groups. In group A, 50 patients were included and given sildenafil citrate $25 \mathrm{mg}$ vaginally every 6 hours for 5 days from day 8 th of the cycle. In group B, 50 patients were given tablet estradiol valerate 2 mg 6-8 hourly. Patients were re-evaluated by TVS on day 13th of cycle for endometrial thickness, pattern, zone wise distribution of blood flow with number and size of Graffian follicle.

Data was then obtained regarding the difference in endometrial thickness, pattern, vascularity and pregnancy rates after 3 cycles of stimulated cycles plus IUI and analyzed to find out the statistical importance of the data obtained.

\section{RESULTS}

Mean age in group A and group B was 26.8 and 28.2 respectively. 42 out of 50 patients $(84 \%)$ in group A had primary infertility whereas it was in 44 patients $(88 \%)$ in group B. None of the patient characteristics was found to be statistically significant (Table 1). Mean endometrial thickness on day 7 was $5.42 \mathrm{~mm}$ in sildenafil group whereas it was $5.76 \mathrm{~mm}$ in estradiol group. The mean of number of follicles $>18 \mathrm{~mm}$ at the time of hcg trigger was 1.52 and 1.68 in the two groups respectively. The difference is again statistically insignificant. 43 out of 50 patients in group a $(86 \%)$ and 41 out of $50(82 \%)$ were stimulated using clomiphene citrate $(50 / 100 \mathrm{mg})$ whereas rest were given gonadotrophins (HMG/FSH). 16 out of 50 couples $(32 \%)$ in group A and 20 out of 50 couples $(40 \%)$ in group B had male factor infertility also and were offered IUI with donor semen (Table 2). None of these cycle characteristics had significant impact on the results obtained.

Table 1: Patient characteristics.

\begin{tabular}{|lll|}
\hline & $\begin{array}{l}\text { Sildenafil group } \\
\text { (A-50 patients) }\end{array}$ & $\begin{array}{l}\text { Estradiol } \\
\text { valerate group } \\
\text { (B-50 patients) }\end{array}$ \\
\hline Mean age (years) & 26.8 & 28.2 \\
\hline Primary infertility & 42 & 44 \\
\hline Secondary infertilit: & 8 & 6 \\
\hline BMI $\left(\mathrm{kg} / \mathrm{m}^{2}\right.$ ) & 23.3 & 22.7 \\
\hline
\end{tabular}

Mean age: group $\mathrm{A}=26.8+/-4.6$; mean age: group $\mathrm{B}=$ 28.2+/- 5.4.

Table 2: Cycle characteristics.

\begin{tabular}{|llll|}
\hline \multirow{2}{*}{ Day 7 endometrial thickness $(\mathrm{mm})$} & Sildenaffl group ( A-50 patients) & Estradiol valerate group (B-50 patients) \\
\hline \multirow{2}{*}{ Stimulation } & Clomiphene citrate & 4.42 & 5.76 \\
\cline { 2 - 4 } & Gonadotrophins & 7 & 41 \\
\hline \multirow{2}{*}{ Type of IUI husband (H)/donor (D) } & $34(\mathrm{H}), 16(\mathrm{D})$ & 9 \\
\hline
\end{tabular}


Mean endometrial thickness at the time of HCG trigger was $9.42 \mathrm{~mm}$ in sildenafil group whereas it was $9.94 \mathrm{~mm}$ in estradiol group. Although the endometrium was found to be thicker in estradiol group, the results were statistically insignificant ( $p$ value 0.14 ). Two out of 50 cycles in estradiol group were cancelled as patients failed to achieve ET $>7 \mathrm{~mm}$ although there was no cancellation in sildenafil group. $74 \%$ patients in group A and $68 \%$ in group B developed trilaminar pattern of endometrium. $64 \%$ patients given sildenafil vaginally had vascularity up to zone 3 whereas $48 \%$ patients given estradiol valerate orally had zone 3 endometrial vascularity ( $p$ value 0.038 ). The result was found to be statistically significant and helpful in the treatment of other patients at our institute. The clinical pregnancy rates after 1 IUI were 6 in group 1 (12\%) and 4 in group $2(8 \%)$ which further rose to 10 (20\%) and $7(14 \%)$ respectively after 3 cycles of IUI (p value 0.042 ). thus a significant increase in clinical pregnancy rates was also observed when sildenafil was used in patients with poor endometrium as compared to estradiol valerate group (Table 3 ).

Table 3: USG monitoring on day of hCG trigger.

\begin{tabular}{|c|c|c|}
\hline & $\begin{array}{l}\text { Sildenafil } \\
\text { group } \\
\text { (A-50 patients) }\end{array}$ & $\begin{array}{l}\text { Estradiol } \\
\text { valerate group } \\
\text { (B-50 patients) }\end{array}$ \\
\hline $\begin{array}{l}\text { Endometrial } \\
\text { thickness (mm) }\end{array}$ & 9.42 & 9.94 \\
\hline $\begin{array}{l}\text { Endometrial pattern } \\
\text { (trilaminar) }\end{array}$ & 37 & 34 \\
\hline $\begin{array}{l}\text { Endometrial blood } \\
\text { flow (zone } 3 \text { ) }\end{array}$ & 32 & 24 \\
\hline $\begin{array}{l}\text { Follicles }>18 \mathrm{~mm} \\
\text { (day of trigger) }\end{array}$ & 1.52 & 1.68 \\
\hline $\begin{array}{l}\text { Cycle cancellation } \\
(\mathrm{ET}<7 \mathrm{~mm} />14 \mathrm{~mm})\end{array}$ & n) & 2 \\
\hline
\end{tabular}

$\mathrm{p}$ value (endometrial vascularity) $=0.038$ (Statistically significant).

Table 4: Clinical pregnancy rates.

\begin{tabular}{|lll|}
\hline & $\begin{array}{l}\text { Sildenafil } \\
\text { group }(\mathrm{A}-50 \\
\text { patients) }\end{array}$ & $\begin{array}{l}\text { Estradiol } \\
\text { valerate group } \\
\text { (B-50 patients) }\end{array}$ \\
\hline After 1 IUI & $6(12 \%)$ & $4(8 \%)$ \\
\hline After 3 IUI & $10(20 \%)$ & $7(14 \%)$ \\
\hline
\end{tabular}

$\mathrm{p}$ value (after $3 \mathrm{IUI})=0.042$ (statistically significant).

\section{DISCUSSION}

The results of the present study were compared to previous studies. In a prospective study by Takasaki et al of 61 patients with a thin endometrium $(8 \mathrm{~mm})$, there was a significant improvement in endometrial thickness in 11 patients. ${ }^{12}$ In a meta-analysis done by Torres RF et al use of pure ethinyl estradiol for treatment of thin endometrium was examined, the observations made were: addition of ethinyl estradiol (EE) does improve the endometrial thickness in comparison to patients where only placebo was used. ${ }^{13}$ Cetinkaya $\mathrm{K}$ et al used vaginally administered local oestrogen $25 \mathrm{mcgms}$ from $4^{\text {th }}$ day for 15 days in clomiphene citrate induced cycle. They reported significant increase in endometrial thickness on the day of ovulation (7.6+/- $1.4 \mathrm{~mm}$ versus $8.3+/-2.1 \mathrm{~mm}$ ) than the group where only clomiphene citrate was used, but there was no change in pregnancy rate. Dose schedule is different from fresh cycle. ${ }^{14}$ Jimenez PT et al used oral estradiol $2 \mathrm{mg}$ thrice daily from day one for 12 days. They reported appropriate development of endometrium in $67 \%$ patients. ${ }^{15}$ Takasaki et al used $100 \mathrm{mg}$ sildenafil intravaginal starting first day of cycle till day of ovulation and $92 \%$ patients showed improvement in endometrial thickness. ${ }^{12}$ Firouzabadi et al used $50 \mathrm{mg}$ orally Sildenafil starting 1st day till 45-72 hours prior to embryo transfer. Endometrial thickness and triple line pattern was found significantly higher with sildenafil and estadiol valerate as compared to estradiol alone. Clinical pregnancy rate was higher but not significant. ${ }^{16}$ Jerzak M et al used 25 mg Sildenafil four times a day for 3 to 6 days as intravaginal suppository. Endometrial thickness was significantly increased. ${ }^{17}$ All these studies further support the present study. Although most of the studies have compared estradiol or sildenafil alone with patient's previous cycle taken as control. Some studies have been published comparing estradiol alone to a combination of estradiol plus Sildenafil also. Present study is one of its own kinds and would need further large randomized control trials to further support the results. To summarize, adequately thick, trilaminar pattern endometrial milieu is important for implantation of the embryo and continuation of pregnancy. Both estradiol and Sildenafil can be used for improving the endometrium (thickness and vascularity) and to support embryo growth. Sildenafil when compared to estradiol valerate has better results as far as endometrial vascularity is concerned and marginally increased pregnancy outcome in patients undergoing IUI. Improving the endometrial blood flow to enable an estrogenic milieu for proliferation remains the cornerstone of achieving adequate endometrial growth and receptivity thus achieving a better pregnancy rate and outcome.

\section{Funding: No funding sources Conflict of interest: None declared Ethical approval: Not Required}

\section{REFERENCES}

1. Schachter M, Strassburger D, Bern O, Ron-El R, Friedler S. Favorable influence of local injury to the endometrium in intracytoplasmic sperm injection patients with high-order implantation failure. Fertil Steril. 2007;87:198-201.

2. Gnainsky Y, Granot I, Aldo PB, Barash A, Or Y, Schechtman E. Local injury of the endometrium induces an inflammatory response that promotes successful implantation. Fertil Steril. 2010;94:2030-6. 
3. Richter KS, Bugge K, Bromer J, Levy M. Relationship between endometrial thickness and embryo implantation, based on 1,294 cycles of in vitro fertilization with transfer of two blastocyststage embryos. Fertil Steril. 2007;87:53-9.

4. Kovacs P, Matyas S, Boda K, Kaali SG. The effect of endometrial thickness on IVF/ICSI outcome. Hum Reprod. 2003;18:2337-41.

5. Wells CS, Williams DB, Odem RR, Gast MJ, Strickler RC. Endometrial thickness is a valid monitoring parameter in cycles of ovulation induction with menotropins alone. Fertil Steril. 1996;65:262-6.

6. Paulson RJ. Hormonal induction of endometrial receptivity. Fertil Steril. 2011;96:530-5.

7. Xhang X, Chen CH, Confino E, Barnes R, Milad M, Kazer RR. Increased endometrial thickness is associated with improved treatment outcome for selected patients undergoing in vitro fertilizationembryo transfer. Fertil Steril. 2005;83:336-40.

8. Gleicher N, Vidali A, Barad DH. Successful treatment of unresponsive thin endometrium. Fertil Steril. 2011;95:2123-3.

9. Tsai HD, Chang CC, Lo HY, Chen CL. Low-dose aspirin for infertile women with thin endometrium receiving intrauterine insemination: a prospective, randomized study. J Assist Reprod Genet. 2000;17:174-7.

10. Bhojwani JT, Marshburn PB, Papadakis MA, Loeb TA, Matthews ML. Low-dose aspirin does not improve ovarian stimulation, endometrial response, or pregnancy rates for in vitro fertilization. J Exp Clin Assist Reprod. 2005;2:8.

11. Michael A. The uterine biophysical profile (UBP). Endosonography in obstetrics and gynaecology.
Gautam Allahabadia (Ed). Rotunda Medical Technologies (P) Ltd. Mumbai, India; 1997:343-52.

12. Takasaki A, Tamura H, Miwa I, Taketani T, Shimamura K, Sugino N. Endometrial growth and uterine blood flow: a pilot study for improving endometrial thickness in the patients with a thin endometrium. Fertil Steril. 2010;93(6):1851-8.

13. Torres RF, Habana AE, Tansengco LG. The Effect of estrogen supplementation on the endometrium and pregnancy rate among infertile women treated with clomifene citrate: a meta-analysis. Fertil Steril. 2005;84:S162-S3.

14. Cetinkaya K, Kadanalı S. The effect of administering vaginal estrogen to clomiphene citrate stimulated cycles on endometrial thickness and pregnancy rates in unexplained infertility. J Turk Ger Gynecol Assoc. 2012;13(3):157-61.

15. Jimenez PT, Schon SB, Odem RR, Ratts VS, Jungheim ES. A retrospective cross-sectional study: fresh cycle endometrial thickness is a sensitive predictor of inadequate endometrial thickness in frozen embryo transfer cycles. Reprod Biol Endocrinol. 2013;11:35.

16. Firouzabadi DR, Davar R, Hojjat F, Mahdavi M. Effect of sildenafi 1 citrate on endometrial preparation and outcome of frozen-thawed embryo transfer cycles: a randomized clinical trial. Iran J Reprod Med. 2013;11(2):151-8.

17. Jerzak M, Kniotek M, Mrozek J, Górski A, Baranowski W. Sildenafi 1 citrate decreased natural killer cell activity and enhanced chance of successful pregnancy in women with a history of recurrent miscarriage. Fertil Steril. 2008;9(5):1848-53.

Cite this article as: Mangal S, Mehirishi S. To study and compare the effect of vaginal sildenafil and estradiol valerate on endometrial thickness, blood flow and pregnancy rates in infertile women undergoing intrauterine insemination. Int J Reprod Contracept Obstet Gynecol 2016;5:2274-7. 